\title{
IdeAs
}

Idées d'Amériques

$17 \mid 2021$

Villes et culture dans les Amériques

\section{American Studies in Italy / Études américaines en Italie / Estudios Americanos en Italia}

\section{Matteo Sanfilippo}

\section{(2) OpenEdition \\ Journals}

Electronic version

URL: https://journals.openedition.org/ideas/10516

DOI: 10.4000/ideas.10516

ISSN: 1950-5701

\section{Publisher}

Institut des Amériques

\section{Electronic reference}

Matteo Sanfilippo, "American Studies in Italy / Études américaines en Italie / Estudios Americanos en Italia", IdeAs [Online], 17 | 2021, Online since 01 March 2021, connection on 03 June 2021. URL: http:// journals.openedition.org/ideas/10516 ; DOI: https://doi.org/10.4000/ideas.10516

This text was automatically generated on 3 June 2021.

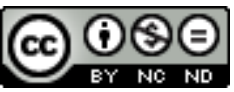

IdeAs - Idées d'Amériques est mis à disposition selon les termes de la licence Creative Commons Attribution - Pas d'Utilisation Commerciale - Pas de Modification 4.0 International. 


\title{
American Studies in Italy / Études américaines en Italie / Estudios Americanos en Italia
}

\author{
Matteo Sanfilippo
}

1 Since the $19^{\text {th }}$ century, American studies in Italy have focused mainly on the political history of the US. This is a direct consequence of the European echo of the "American Revolution" and of the "great" Italian migration to North America at the end of the century ${ }^{1}$. Consequently, during the following century, attention to Latin America was unstable and erratic and was circumscribed to the study of particular flows of Italian migration across the Atlantic, for example the "fascist" migration, or to peculiar political moments, such as the Cuban revolution or the rise of populism in the second half of the century. Moreover, at the core of Italian studies on Latin America is the analysis of US hegemony in the Southern continent, thus making them a branch of US history $^{2}$. During the same century, Canada was peripheral to the Italian understanding of the Americas, but, since the 1970s, a small group of researchers has worked on relations between the Holy See, Canada and the US, exploiting Vatican sources ${ }^{3}$.

2 Throughout the $20^{\text {th }}$ century, Italian "Americanists" mainly focused their concern on US history. In the early 1960s, Agostino Lombardo stated that this was the byproduct of the discovery and of the Italian success of American writers, but we should not forget the Fascist and later Christian Democrat sympathies for the US, considered as the most important country of Italian immigration ${ }^{4}$. Moreover, in the 1930s, there was a similarity between the Fascist and the New Deal approaches to the economic crisis, therefore the Fascist government closely studied the US economic strategy. Political and economic relations grew even closer during the postwar period and the Cold War ${ }^{5}$.

In a way, the latter was instrumental in imposing US studies in the Italian Academy. To win over Italian intellectuals, the US embassy in Rome started numerous (and glamorous) projects, including grants to visit and to study in prestigious US universities and financial support to hire teachers of American history in Italian universities. At the same time, a number of historians were drawn to the US, because of 
their religious (the Protestant and Socialist historian Giorgio Spini), or political affiliations (liberal-democrat historian Massimo Teodori; military historian Raimondo Luraghi) ${ }^{6}$. Therefore, they pursued two distinct lines of research: the first linking the origins of the colonial experience to the growth of democracy, with special attention to the religious sphere; the second reflecting on the values and vicissitudes of US democracy?

Due to the lobbying efforts of the US embassy, but also insistance from the abovementioned Italian scholars, between the late 1970s and the beginning of the 1980s, US history studies were included in the academic teaching curriculum. Other nations, for example Canada, tried vainly to follow the same path, while Spanish- and Portuguesespeaking countries were from the start considered to be part of a political reality extending from Mexico to the South Pole that had to be studied as a whole ${ }^{8}$. In 1986, Tiziano Bonazzi, full professor of History and the Institutions of North America, attributed the boom in his field of studies to the country's cultural "Americanization" after World War II. He therefore emphasized the love-hate relationship with the US that hid behind the genuine, yet mostly, according to him, inexplicable interest in American history in Italy'.

In the early 1990s, Flavio Fiorani launched the collection "Americana", 15 books on the history of the Americas since the European "discovery" and conquest, authored by a new generation of historians interested not only in the history of the US and of "Latin America", but also in that of Canada and of native peoples. Some of these books were reprinted in the new millennium, but this was the last effort to enlarge the dimension and the audience of academic American studies in Italy. Since then, the production of books has been geared to a few and well popular topics, such as the history of the US West, the US Civil War, or New York ${ }^{10}$.

6 Since the 1970s scholarly associations and research centers have tried to support the growth of North American studies in and around Italian universities. However, they were unable to consolidate the field. Thus, in the new millennium, the number of teaching positions for American studies has declined, while former professors of North or South American history chose to teach general Modern or Contemporary History. Therefore, in the academic year 2020-2021, we have only 11 teaching positions (in 96 Italian universities) in American history: 7 in US, 3 in Latin America, 1 in the Americas generally.

7 At the same time, Italian curiosity for US history and culture has not diminished: the Biden-Trump duel was widely followed (also for its political repercussions in Italy). But this curiosity is satisfied mainly by journalists, media commentators, and diplomats writing books about their experiences, even if there are number of scholars in Academia specialized in US politics. Even in the more important sectors of Italian scholarship on the Americas, for instance the study of migration to the US and ItalianUS relations ${ }^{11}$, books by scholars have not succeeded in reaching a wider audience. And the same goes for publications on the relations between the United States and the world or trends in Western civilization and US influence ${ }^{12}$.

8 Considering this lack of readership for academic studies, even the history of women and the history of Blacks, fields of research that were very popular at the end of the $20^{\text {th }}$ century, are not doing well ${ }^{13}$. Therefore, it seems useless to explore the lines of research of academic American (i.e., as already stated, US) studies today. Nevertheless, since the 1980s, specialists in American literature or in comparative literatures have 
been developing an approach to American culture that is more appealing (and more widely read) than the historical one ${ }^{14}$. Moreover, at times, collaboration between historians and literary critics allows for access to a wider audience: this for example has been the experience of Acoma, a North American Studies biannual publication printed in the past 27 years by a group of academics (see its site: acoma.it). In its monographic issues, this journal renews old lines of research by combining history, literature and communication studies.

In fact, new prospects for American studies in Italy, in particular for American historical studies, have perhaps been opened by academic journals, in particular if they are on-line. There are traditional ones that have started a blog on their site, offering more material than in the printed edition (see Ricerche di storia politica, http:// www.arsp.it/). Other traditional ones-have decided to cross the frontier between two or more disciplines: a good example of this trend is the issue The New Language of American Democracy of the journal Costellazioni. Rivista di lingue e letterature (https:// www.rivistacostellazioni.org/). Some digital journals also cross the same boundaries, such as Iperstoria. Journal of American and English Studies (Iperstoria.it) and USAbroad. Journal of American History and Politics (usabroad.unibo.it/), or the blog www.ceraunavoltalamerica.it/, linked to the Centro Interuniversitario di Storia e Politica Euro - Americana. But we should not forget the digital version of traditional publications such as RSA Journal (https://www.aisna.net/journal/), printed by the Associazione Italiana Studi Nord Americani.

10 To conclude, American studies in Italy are a very frail academic field, too focused on US history, while unable to analyze in depth the society, the economy, the culture and the political debate of the two Americas. Moreover, there is a lack of financing of these studies, even of the historical ones, by the government and the universities. Therefore any progress made in the discipline remains too slow and based on individual efforts.

\section{NOTES}

1. Giovanni Pizzorusso and Matteo Sanfilippo, Viaggiatori ed emigranti. Gli italiani in Nord America, Viterbo, Sette Città, 2004. I thank Roberto Perin (York University, Toronto) for revising the first draft of this paper.

2. Eugenia Scarzanella (ed.), Fascisti in Sud America, Firenze, Le Lettere, 2005; Angelo Trento, La rivoluzione cubana, Firenze, Giunti, 2002; Loris Zanatta, Il populismo gesuita. Perón, Fidel, Bergoglio, Roma-Bari, Laterza, 2020. Raffaele Nocera, Stati Uniti e America Latina dal 1823 a oggi, Roma, Carocci, 2009.

3. Martin Pâquet, Matteo Sanfilippo and Jean-Philippe Warren (eds.), Le Saint-Siège, le Québec et l'Amérique française. Les archives vaticanes, Sainte-Foy, PUL, 2013; Matteo Binasco, Roman Sources for the History of American Catholicism, 1763-1939, Notre Dame, Notre Dame University Press, 2018; Luca Codignola, Blurred Nationalities across the North Atlantic: Traders, Priests, and Their Kin Travelling between North America and the Italian Peninsula, 1763-1846, Toronto, UTP, 2018.

4. Agostino Lombardo, La ricerca del vero: saggi sulla tradizione letteraria americana, Roma, Edizioni di Storia e letteratura, 1961, p. 13-61. On Fascism and the US, the bibliography is very vast, cf. 
Matteo Pretelli, La via fascista alla democrazia americana. Cultura e propaganda nelle comunità italoamericane, Viterbo, Sette Città, 2012.

5. Maurizio Vaudagna (ed.), The New Deal and the American Welfare State. Essays from a transatlantic perspective (1933-1945), Torino, Otto, 2013. Leopoldo Nuti, Gli Stati Uniti e l'apertura a sinistra. Importanza e limiti della presenza americana in Italia, Roma-Bari, Laterza, 1999; Francesca Fauri, Il Piano Marshall e l'Italia, Bologna, il Mulino, 2010; Federico Romero, Storia della guerra fredda, Torino, Einaudi, 2014.

6. Umberto Eco, Gian Paolo Ceserani and Beniamino Placido, La riscoperta dell'America, Roma-Bari, Laterza, 1984.Tiziano Bonazzi, « Giorgio Spini e l'inizio degli studi di storia statunitense in Italia, »Quaderni del Circolo Rosselli, 137, 2020, p. 51-58.

7. Massimo Rubboli, Alle origini della storia americana. I Padri pellegrini tra storia e mito (1620-2020), Milano, Unicopli, 2020. Giovanni Borgognone, Storia degli Stati Uniti. La democrazia americana dalla fondazione all'era globale, Milano, Feltrinelli, 2016.

8. Marcello Carmagnani, L'America latina dal '500 a oggi. Nascita, espansione e crisi di un sistema feudale, Milano, Feltrinelli, 1975.

9. Luca Codignola, « On the Witness Stand: A Prosopography of American History in Italy in the Post-War Decades, 1945-1978, » in Massimo Bacigalupo and Gregory Dowling (eds.), Ambassadors. American Studies in a Changing World, Rapallo, Busco, 2006, p. 120-159; Maurizio Vaudagna, " American Studies in Italy: Historical Legacies, Public Contexts and Scholarly Trends, » Storia della Storiografia, 51, 2007, p. 17-63; Tiziano Bonazzi, « American History: The View from Italy, » Reviews in American History, 14, 4 (1986), p. 523-541. On the love-hate relationship: Massimo Teodori, Maledetti americani. Destra, sinistra e cattolici: storia del pregiudizio antiamericano, Milano, Mondadori, 2003, and Piero Craveri and Gaetano Quagliariello (eds.), L'antiamericanismo in Italia e in Europa nel secondo dopoguerra, Soveria Mannelli, Rubbettino, 2004.

10. Bruno Cartosio, New York e il moderno. Società, arte e architettura nella metropoli americana (1876-1917), Milano, Feltrinelli, 2007, and Verso Ovest. Storia e mitologia del Far West, Milano, Feltrinelli, 2018; Tiziano Bonazzi, Abraham Lincoln. Un dramma americano, Bologna, il Mulino, 2016, and La rivoluzione americana, Bologna, il Mulino, 2018.

11. For the presidential election: Ferdinando Fasce, I presidenti USA. Due secoli di storia, Roma, Carocci, 2011. For migrations and political or diplomatic relationship: Stefano Luconi and Matteo Pretelli, L'immigrazione negli Stati Uniti, Bologna, il Mulino, 2008; Lucia Ducci, Stefano Luconi and Matteo Pretelli, Le relazioni tra Italia e Stati Uniti. Dal Risorgimento alle conseguenze dell'11 settembre, Roma, Carocci, 2012; Daniele Fiorentino, Gli Stati Uniti e il risorgimento d'Italia (1848-1901), Roma, Gangemi, 2014; Lorenzo Benadusi, Daniela Rossini, and Anna Villari (eds.), 1917. L'inizio del secolo americano. Politica, propaganda e cultura in Italia tra guerra e dopoguerra, Roma, Viella, 2018.

12. Raffaella Baritono and Elisabetta Vezzosi (eds.), Oltre il secolo americano? Gli Stati Uniti prima e dopo l'11 settembre, Roma, Carocci, 2011; Marco Mariano, L'America nell'«Occidente». Storia della dottrina Monroe (1823-1963), Roma, Carocci, 2013; Mario Del Pero, Libertà e impero. Gli Stati Uniti e il mondo 1776-2016, Roma-Bari, Laterza, 2018.

13. Ferdinando Fasce, « Fifty Years On. Italian Historians of the United States and Italian History, Culture, and Public Life, 1960-2010, " Storia della Storiografia, 70, 2016, p. 43-71.

14. Franco Moretti, Un paese lontano. Cinque lezioni sulla cultura americana, Torino, Einaudi, 2019; Alessandro Portelli, Il ginocchio sul collo. L'America, il razzismo, la violenza tra presente, storia e immaginari, Roma, Donzelli, 2020. 


\section{AUTHOR}

\section{MATTEO SANFILIPPO}

Matteo Sanfilippo est titulaire de la chaire d'histoire moderne à l'Università della Tuscia (Viterbe, Italie) et dirige l'Istituto Storico Scalabriniano (Rome). Il co-dirige les revues Studi Emigrazione et Archivio storico dell'emigrazione italiana et est l'auteur d'une trentaine de volumes, dont L'emigrazione nei documenti pontifici (2018) et Storie, epoche, epidemie (2020). 